\title{
Documentation Status, Gender, and Health Selection of Immigrants: \\ Evidence from Mexican-US Migration
}

\author{
Yao $\mathrm{Lu}^{1}$, Xiaoguang $\mathrm{Li}^{2}$ \\ 1. Columbia University, New York, US \\ 2. Hong Kong University of Science and Technology, and Xi'an Jiaotong University, China
}

\section{Full citation:}

Lu, Yao, and Xiaoguang Li. 2020. "Documentation Status, Gender, and Health Selection of Immigrants: Evidence from Mexican-US Migration." Population, Space and Place 26(7): e2333.

\section{Correspondence:}

Yao Lu

501 Knox Hall

606 West 122nd Street

New York

USA

Email: yao.lu@columbia.edu

\section{Acknowledgments:}

The authors gratefully acknowledge support from the National Institute of Child Health and Development (1K01HD073318), the Columbia Population Research Center with funding from the National Institute of Child Health and Human Development (P2CHD058486), and the Institute of Latin American Studies at Columbia University. The authors thank Karen Pren for valuable suggestions. 


\title{
Documentation Status, Gender, and Health Selection of Immigrants: Evidence from Mexican-US Migration
}

\begin{abstract}
Recent research has revealed an epidemiologic paradox within immigrants: undocumented immigrants often exhibit similar or even better health outcomes than documented immigrants despite their socioeconomic disadvantages. The present study examines whether this paradox partly reflects heterogeneity in immigrant health selection by documentation status and gender. We examine the case of Mexico-US immigration using data from the Mexican Migration Project, which provides pre-migration health and detailed migration histories. Results demonstrate notable diversity in immigrant health selection. Undocumented Mexican immigrant men are especially positively selected on health. Better pre-migration health also increases recurrent undocumented migration trips. Documented Mexican immigrant men, in contrast, do not exhibit a significant level of positive health selection. For Mexican women, both documented and undocumented migrants are positively selected on the basis of health, and the degree of health selection is irrespective of their documentation status. These findings suggest that immigrant health selection can operate differently depending on the risks and maturity of migration. Taking into account both documentation status and gender is essential for a more accurate understanding of immigrant health selection and has important implications for investigating the impact of undocumented status on immigrant health.
\end{abstract}

\section{Key words}

Healthy migrant effect, selection, documentation status, gender, Mexican-US migration. 


\section{Introduction}

There is mounting research that has investigated a "healthy immigrant effect" across societies (Akresh and Frank, 2008; Andersson and Drefahl, 2017; Chiswick et al., 2008; Lu, 2008; Lu and Qin, 2014; Rubalcava et al., 2008; Ullmann et al., 2011; Riosmena et al., 2013, 2017; Wallace and Kulu, 2014, 2018; Kennedy et al., 2015; Anglewicz et al., 2018; Diaz et al., 2018): healthier individuals are more likely to undertake migration than their less healthy peers in their countries of origin. Health may directly influence migration because healthier persons can better endure the physical, emotional, and institutional challenges incurred in migration and subsequent adaptation. Migrants may also appear to be healthier than nonmigrants because they are favorably selected on the basis of socioeconomic and demographic characteristics that foster good health. However, previous research shows that even after adjusting for sociodemographic factors, migrants remain selective of those with superior health (Anglewicz et al., 2018; Diaz et $a l ., 2018)$, pointing to a direct influence of health on migration behavior.

The positive health selection of immigrants constitutes a primary explanation for an "immigrant health paradox": despite lower levels of socioeconomic status and limited access to health services, immigrants in the United States and other main destination countries (e.g., UK, Canada, and Australia) exhibit more favorable health outcomes than the native-born population. This paradox is found in mortality and morbidity rates, chronic conditions, and mental health (Hayward and Heron, 1999; Abraído-Lanza et al., 2005; Antecol and Bedard, 2006; Castro, 2007; Halliday and Kimmitt, 2008; Kennedy et al., 2015).

However, empirical research does not consistently support the "healthy immigrant effect" (Abraído-Lanza et al., 1999; McDonald and Kennedy, 2004; Akresh and Frank, 2008; Lu, 2008; Rubalcava et al., 2008; Wallace and Kulu, 2014; Kennedy et al., 2015). The inconsistencies may 
be partly attributed to a diversity in immigrant health selection. If the degree of health selection varies by certain characteristics of migrants, such as documentation status or gender, studies that combine different migrant groups tend to obscure these differences. The present study seeks to bridge this gap by examining two underinvestigated factors in the "healthy immigrant effect," namely documentation status and gender, and investigating how they combine to shape the health selection process.

First, are undocumented immigrants more or less positively selected on health than their documented peers? Understanding differential health selection by immigrant status is necessary for an accurate appraisal of the impact of documentation status on immigrant health. Legal status has been perceived as a fundamental cause of health (Castañeda et al., 2015; Torres and Young, 2016; Asad and Clair, 2018). Undocumented immigrants confront precarious conditions and heightened stressors in an increasingly restrictive and hostile environment (Briggs, 1993; Hall and Greenman, 2015), well beyond the hardships typically experienced by documented immigrants. These conditions are expected to compromise the health of unauthorized immigrants. However, an increasing body of research points to an epidemiologic paradox within immigrants with respect to documentation status (Wen and Maloney, 2014; Swartz et al., 2017; Young and Madrigal, 2017; Hamilton et al., 2019): undocumented immigrants often exhibit similar or even better health outcomes than documented immigrants in spite of their socioeconomic disadvantages.

This paradox may be partially explained by differential immigrant health selection. Immigrant selectivity generally rises with the costs and risks of migration (Jasso and Massey, 2004; Orrenius and Zavodny, 2005; Docquier and Rapoport, 2009). Compared to authorized immigration, the costs and risks of unauthorized immigration are substantially higher. This 
would lead to a more pronounced healthy immigrant effect for undocumented immigrants. The greater selectivity allows unauthorized immigrants to endure risky border crossing and precarious living and working conditions after migration. Less healthy individuals, by contrast, are less likely to undertake undocumented migration because of a lower likelihood of successful border crossing and economic integration.

Second, does immigrant health selection vary by gender? In particular, does differential health selection by documentation status hold for both men and women? Gender organizes the social structures and relations that shape the causes, process, and consequences of migration (Curran et al., 2006; Donato and Gabaccia, 2015). In this respect, the risks and benefits of migration may differ by gender, which may factor into men and women's migration decisions in distinct ways. For instance, to the degree that women rely more heavily on existing migration networks that provide informational and monetary resources, undocumented immigration may entail lower risks for women than for men. We would thus expect a greater positive health selection for undocumented migration to be less salient among women than among men.

To address these two questions, the present study examines how immigrant health selection patterns differ by documentation status and by gender. The analysis is conducted in the context of Mexico-US migration. Mexico has a long history of migration to the United States (Massey et al., 2002; Garip, 2012; Villarreal and Hamilton, 2012). It is the primary source country for undocumented immigrants to the US. An estimated 10.5 million immigrants are undocumented, among which nearly 50\% originate from Mexico (López et al., 2017; Krogstad et al., 2019). We draw on rich data from the Mexican Migration Project, which includes premigration health and detailed migration histories (including documentation status). We focus on the direct influence of health on migration by controlling for a range of sociodemographic 
characteristics. We conducted statistical analysis separately for men and women. Within each gender, we compared documented and undocumented immigrants with nonmigrants in Mexico. The results demonstrate substantial diversity in the immigrant health selection process.

\section{Documentation Status and Immigrant Health Selection}

Documentation status constitutes a key differentiating factor among immigrants. Unauthorized Mexican immigrants lack basic rights and labor protections; they also face precarious working conditions and constant threats of apprehension and deportation (Torres and Young, 2016;

Waters and Pineau, 2016). These conditions are likely to have adverse impacts on their physical and mental health.

Despite these concerns, empirical studies do not consistently find that undocumented immigrants are at a health disadvantage. A recent study (Hamilton et al., 2019) finds a lower risk of chronic conditions and pain among unauthorized Mexican farm workers than their authorized counterparts. The result holds even after controlling for time in the US and access to health care. The study further reviews 12 articles on health disparities between authorized and unauthorized US immigrants. The authors find that in this line of work, rather than a health disadvantage, unauthorized immigrants are found to be at a health advantage or have no significant difference from their documented counterparts (Wen and Maloney, 2014; Swartz et al., 2017; Young and Madrigal, 2017). Specifically, among all 45 comparisons of physical health outcomes in the 12 studies reviewed, $93 \%$ show no difference or better outcomes for unauthorized immigrants.

A possible explanation for this paradox may trace back to health differences between the two groups of immigrants prior to migration, that is, differential health selection by documentation status. On a general level, the physical and mental demands of the migration 
journey and subsequent settlement prevent frail individuals from migrating (Palloni and Morenoff, 2001). Furthermore, immigrant selectivity rises with the costs and risks of migration (Jasso and Massey, 2004; Orrenius and Zavodny, 2005; Docquier and Rapoport, 2009). This suggests that undocumented immigration may amplify health selectivity because it involves greater risks and demands.

For one thing, the migration journey for unauthorized immigrants to the US is much more taxing and risky than that for authorized immigrants. The trip often entails perilous crossings of thousands of miles of shrublands and desert (Aguirre and Simmers, 2008). Increased border enforcement further heightens the risk and costs of illicit border crossing. To evade gangs and border patrol officers, Mexican immigrants increasingly take less charted, geographically harsher, and more dangerous routes than before (Cornelius, 2001). These circumstances require greater physical stamina and strength. Those who have the health and strength to make the journey are more likely to undertake clandestine migration.

Additionally, upon arrival, the living and working conditions are more precarious and physically demanding for unauthorized immigrants. Undocumented immigrants rely heavily on social networks in settlement and employment (Massey and Espinosa, 1997; Hagan, 1998; Livingston, 2006; Massey et al., 2014). Following their predecessors, they are thus disproportionately channeled into 3D jobs (dirty, dangerous, and demanding), shunned by nativeborn workers and even documented immigrants (Briggs, 1993; Hall and Greenman, 2015). In this respect, healthy individuals are more likely to carry out strenuous physical labor, and thus sustain their lives by garnering economic returns from unauthorized immigration than less healthy persons.

On the other hand, there is reason to expect more favorable health selection for 
documented immigrants. In the US, authorized immigrants (i.e., permanent residents and temporary immigrants staying for over six months) are subject to health screening. The screening process includes a comprehensive review of one's medical history, standard physical examinations, and basic blood tests and x-rays. It covers a range of communicable diseases, chronic conditions, mental health conditions, and substance abuse. Individuals with better health are more likely to pass the health screening process and immigrate to the US legally (Chiswick et al., 2008). In reality, however, health screening is unlikely to be a principal factor in immigrant health selection because health-based rejection is extremely low (Wasem, 2014; Lu et al., 2017). In 2013 , for example, only $1.6 \%$ of permanent immigrants were judged to be inadmissible on health grounds (U.S. Department of State, 2013). Of those, a majority eventually overcame their ineligibility for admission.

Thus, we expect there to be an overall greater level of positive health selection for undocumented Mexican immigrants than documented immigrants. Risky border crossing, combined with demanding life conditions, can lead to a higher degree of health selection for undocumented immigrants. The same processes can also increase the likelihood of repeated clandestine migrations, in that healthier individuals are more likely to make recurrent unauthorized trips than their less healthy peers.

Previous research on the health selection of Mexican immigrants has yielded mixed findings. Some studies have found only weak evidence of positive health selection (AbraídoLanza et al., 1999; Akresh and Frank, 2008; Rubalcava et al., 2008). The discrepancies result from differences in the timing at which health is measured (prior to or after migration) and the measures used (self-reports or biomarkers) (Rubalcava et al., 2008; Beltrán-Sánchez et al., 2016; Diaz et al., 2018). We contend that an additional reason may be that most previous studies do not 
distinguish between documented and undocumented migration. Combining the two groups would obscure the picture if health selection differed by immigrant status, specifically if positive health selection were largely limited to unauthorized immigrants. Akresh and Frank (2008) find weak support for positive health selection among documented immigrants from Mexico. This finding is not entirely surprising, considering the declining immigrant selectivity over the longhistory of Mexico-US migration. In the early stages of migration, Mexican immigrants were highly selected with respect to sociodemographic characteristics. The characteristics of Mexican migrants progressively broadened as migration matured in local communities and barriers for new migrants continued to decrease (Massey et al., 1994). This process is especially salient for authorized migration. Unauthorized immigrants, by contrast, confront consistently high barriers because of tightening border control. Hence, personal characteristics such as health tend to become relatively less important over time in shaping authorized migration but not necessarily unauthorized migration.

Immigrant health selection by documentation status has not been well studied, with one notable exception. Cheong and Massey (2018) provide one of the first empirical investigations and find no significant difference in health selection by status. Our study builds on this research by conducting a separate analysis of gender. We contend that the mechanisms for immigrant health selection operate differently for men and women. Disaggregating by gender improves our understanding of the selection process.

\section{Gender, Documentation Status, and Immigrant Health Selection}

Previous research has underscored the centrality of gender in the migration process (Curran et al., 2006; Donato and Gabaccia, 2015). This line of work emphasizes that "the migration process 
was inherently different for men and women and/or that the process was influenced by gendered interactions and practices embedded in institutions and organizations" (p209, Curran et al. 2006).

With respect to gender differences in immigrant health selection, the literature offers opposing views. One perspective contends that female immigrants are less selected than male migrants because women disproportionately migrate for family rather than economic reasons (Hamilton et al., 2015; Riosmena et al., 2017; Anglewicz et al., 2018). The alternative view suggests that female migrants may exhibit a high level of selectivity because female migration lags behind male migration (Reichert and Massey, 1980). Men have historically dominated Mexico-US migration (Pedraza, 1991; Cerrutti and Gaudio, 2010). Over time, selectivity in migration has declined for men but not women (Durand et al., 2001; Feliciano, 2005; Garip, 2012). Personal characteristics such as health may still constitute an important factor in women's migration decision-making, even for authorized migration. This explains the finding of a more persistent positive health selection for women than for men (Rubalcava et al., 2008).

When comparing women, two reasons lead us to expect limited differences in positive health selection by documentation status. First, undocumented border crossing is a gendered process (Donato et al., 2008), resulting in lower risks associated with the undocumented migration journey for women than for men. In Mexico, women often follow family members who migrated first. Family migration networks provide informational and monetary resources that mitigate the risks of illegal border crossing (Davis and Winters, 2001). For example, Mexican women are more likely to migrate with family or friends or rely on the assistance of paid smugglers (Donato et al., 2008). Families and friends also offer information on established, less risky routes and ways to prepare for the strenuous journey. These strategies lower the risks of apprehension while increasing the chance of successful clandestine border crossing. 
Second, unauthorized female immigrants are less likely to seek employment and more likely to assume family responsibilities than their male counterparts (Kanaiapuni, 2000). A 2009 Pew report shows that the labor force participation rate of unauthorized female immigrants in the US is $58 \%$, significantly lower than unauthorized male immigrants (94\%) and, to a lesser degree, than authorized female migrants (66\%) (Passel and Cohn, 2009). Undocumented migrant women who do work tend to occupy less physically-demanding jobs in the service sector (Davis and Winters, 2001). By contrast, unauthorized male migrants often assume the primary economic responsibility of the family and undertake strenuous jobs (e.g., construction, agriculture).

Taken together, the less risky migration process, coupled with the lower rate and less strenuous employment of unauthorized immigrant women, tends to place little additional premium on health relative to their authorized peers. This would translate into similar levels of positive health selection between authorized and unauthorized female migrants.

\section{Data and Methods}

\section{Data}

Data were from the Mexican Migration Project (MMP). The MMP has conducted random household ethnosurveys in selected rural and urban communities throughout Mexico since 1982. Three to five communities were surveyed each year between December and the following January. Within each selected community, about 200 households were surveyed via simple random sampling. The representation and quality of the MMP have been validated by systematic comparisons with nationally representative data (Massey and Zenteno, 2000). We used MMP170, which contained data on 176,701 individuals from 170 Mexican communities across 24 states in Mexico. 
The MMP has unique advantages for studying our research questions because it collects information on health prior to migration, on documentation status of migration trips, and on nonmigrants who have stayed in Mexico. This overcomes a major empirical challenge in immigrant health selection research — the lack of data on health prior to migration and on the appropriate group for comparison (i.e., nonmigrants) (Lu, 2008). Ideally, we would like to use prospective longitudinal data with information on health for both immigrants and nonmigrants in sending areas. Such data are rare and, when available, do not necessarily provide information on documentation status.

Crucial to our study, the MMP contains complete retrospective US migration histories of heads of household and their spouses. By definition, MMP does not count short family visits and vacations as US migration trips. MMP asks about the documentation status of the first and last (most recent) trip for heads of household and their spouses. Whereas retrospective data collection may be susceptible to recall bias, previous research has shown that individuals could remember details of major life events, such as migration, relatively well (Smith and Thomas, 2003). This was confirmed by internal consistency checks conducted by MMP, which demonstrated high accuracy in reports of retrospective migration history (Massey et al., 1987).

Our sample included heads of household and their spouses because information on health was collected solely from these two groups. We included both heads of household and spouses to obtain sufficient sample sizes by gender. We restricted the analysis to individuals surveyed after 2007, the year when health information was first collected by the MMP (16,933 persons). We then restricted our sample to persons aged 15 to 55 at the time of the interview (11,835 persons), and excluded 311 persons who migrated to the US when they were under the age of 15 . These restrictions helped improve the recall accuracy for early-life health and migration histories. We 
further excluded 1,330 individuals who had only made domestic migration trips. This permitted us to have a clear comparison between immigrants and nonmigrants in Mexico. These procedures resulted in a sample of 10,194 individuals surveyed between 2007 and 2018 from 56 communities.

\section{Variables}

We examined two dependent variables. The first was a categorical variable indicating an individual's migration and documentation status on his or her first trip. We distinguished among individuals who never migrated to the US, those who first migrated to the US (on or after the age of 15) without documentation, and those who first migrated to the US (on or after the age of 15) with documentation. Following previous research practices, a migrant was treated as undocumented if she or he migrated with no documentation or false documentation (Massey, 2004; Cheong and Massey, 2018). We focused on the first US migration trip to obtain a clean test of immigrant health selection. The use of later migration trips tends to obscure the effect of migration on health and the effect of health on migration.

The second dependent variable was a continuous variable indicating the total number of undocumented US migration trips. For heads of household and spouses, MMP collected information on all undocumented border crossings. We calculated the total number of unauthorized border crossings to the US.

The key independent variable was health, measured by the global measure of self-rated health (SRH). In the MMP, heads of household and spouses were asked, "How do you consider

your health" at several points in their lives. For both migrants and nonmigrants, we used health at age 14 because it captured health status before their first US migration trips (since the age of 15). 
SRH was asked for other points in time: just prior to the most recent US trip (for migrants only), just after the most recent US trip (for returned migrants only), the year before the survey, and at the time of the survey. We did not use SRH at these time points because they were either not consistently available for the entire analytic sample or measured health after migration.

Previous research demonstrates that SRH is consistent with objective measures of health and highly predictive of subsequent morbidity and mortality (Idler and Benyamini, 1997; Biddle et al., 2007; Chiswick et al., 2008). This is the case in Mexico (Subramanian and Kawachi, 2006; Angel et al., 2010). Although SRH is subjective, it reflects perceived health based on individual experiences. Perceived health is likely to play an important role in migration decision-making because it is consciously experienced and internalized.

The SRH question had four categories: excellent, good, regular, or poor, consistent with the convention in measuring self-rated health (Ullmann et al., 2011). We constructed a dichotomous variable, with excellent health coded as $1(33 \%)$ and 0 otherwise $(67 \%)$. We conducted two additional analyses with different operationalization of the health variable. We first categorized SRH into three categories: excellent (33\%), good (64\%), and regular or poor (3\%). We also treated SRH as a continuous variable to capture subtle changes across the health spectrum. These additional analyses generated similar results (Appendix A). We have noted that if the head of household was absent during the survey, another household member (usually the spouse) was chosen to provide proxy reports for the head. To address potential bias of the proxy report, we controlled for self-report versus proxy-report in all analyses.

We drew on a well-developed body of research on migration to construct a rich set of control variables. These variables included age, marital status, years of education, business ownership, home ownership, height (in centimeters), whether or not the individual ever smoked, 
whether the individual's relatives ever migrated, the migration prevalence ratio of the individual's community, availability of irrigation in the municipality, rural vs. urban residence, the state of residence, and survey year. Inclusion of these variables allowed us to examine the direct effect of health on migration (versus health selection due to demographic and socioeconomic factors). In essence, we compared individuals with different health statuses but who were otherwise similar in terms of these aforementioned factors.

As discussed below, because we conducted event-history analysis, we converted the data to a person-year format and constructed these measures as time-varying variables to the extent possible. To convert person-level data to person-year data, we constructed one observation for each individual each year since the age of 15 to the year of the first US migration trip (or to the survey year for nonmigrants). In each observation (person-year), we had information on migration status, along with the individual, household, and community characteristics in that year.

Specifically, age indicated an individual's age in each person-year during the risk set. Marital status was a binary measure of whether the respondent was married or in a consensual union in each person-year, using marital histories in the MMP. For education, we used information on the total years of education and assumed individuals began school at age 6 . In the person-years before an individual obtained his or her highest level of education, we calculated the years of education received by the person up to that year. Education took the value of the total years of schooling for all person-years after the individual finished school. We measured household socioeconomic background by taking in account business ownership and home ownership. Business ownership was a dichotomous variable indicating whether the person had a business during or prior to a given person-year, using information on the start year of the 
business. In a similar vein, we constructed a dichotomous variable of home ownership in a person-year using information on the year for which the house, lot or apartment was acquired. Whereas the MMP contained other socioeconomic variables, they were measured only once at the time of the survey (after migration) and could not be included in models predicting the first migration trip.

We also controlled for early-life health endowments and risk behaviors (Case and Paxson, 2010) including height and whether the individual ever smoked in a given person-year. We estimated similar models without controlling for these variables and obtained similar results (Appendix A). Moreover, a strong predictor of Mexico-US migration is the existence of migrant networks (Cheong and Massey, 2018). We controlled for two network measures at the family and community level. At the family level, we included whether the respondent's parent or sibling ever migrated to the US on or before a given person-year (using information on the first US migration trip, available for all household members). At the community level, we included the migration prevalence ratio, which measured the proportion of individuals (ages 15 or older) in a community who had ever migrated to the US on or before a given person-year.

Other variables included rural versus urban residence, irrigation in municipality, state of residence, and survey year dummy variables. Metropolitan and small urban areas were categorized as urban, while towns and ranchos were classified as rural. Irrigation in municipality was a binary indicator of whether irrigation was available in the municipality (roughly equivalent to a US county), which has been linked to migration (Benonnier et al., 2019).

The amount of missing data in the MMP was small. We dropped less than $1.6 \%$ of individuals with missing data on any variables included in the analyses (for documentation status 
for example, only one immigrant had missing data and was dropped). The final analytic sample consisted of 10,032 individuals.

\section{Methods}

We estimated discrete-time competing-risk event history models (Guo, 2010) to examine the likelihood of initial US migration with or without documentation based on pre-migration health. The competing-risk event history model allows for inclusion of right-censored data (i.e., migration has not occurred within the observation window) and of time-varying covariates. The model also permits inclusion of the three-category outcome variable of interest, which distinguishes among nonmigrants, undocumented US immigrants (on their first trip), and documented US immigrants (first trip).

In the analysis, we first constructed life histories for each individual by converting person-level data into person-year data (discussed above). In the next step, we used multinomial logit models to estimate the likelihood of documented vs. undocumented US migration trip (the reference category was nonmigrants) based on health prior to migration and a range of covariates discussed above. The model is specified as:

$$
\log \frac{P_{m}\left(x_{i}\right)}{P_{M}\left(x_{i}\right)}=\beta_{m} x_{i}, \quad m=1,2, \ldots, M-1 .
$$

where $x_{i}$ denotes all independent variables including health, and $\beta_{m}$ indicates the coefficient for the $m t h$ outcome (nonmigrants are the reference group; $\beta_{M}=0$ ). We estimated the model separately for men and women. There were 4,587 male heads of household or spouses in the analytic sample, which contributed 93,551 person-years to the analysis. There were 5,445 female heads of household or spouses in the analytic sample, which contributed 127,620 person-years to the analysis. 
To examine the number of undocumented trips, which was a count variable, we used negative binomial regressions. We conducted sensitivity analyses to compare the fit of alternative count models, such as poisson and zero-inflated regressions. Fit statistics showed that the negative binomial model yielded the best fit. In the analysis, we controlled for the same set of control variables as the event history analysis. Age, years of education, marital status, business ownership, home ownership, relative ever migrated, migration prevalence ratio, and ever smoked were measured in the year before the first US trip (for immigrants) or the survey year (for nonmigrants). We also included time-invariant control variables such as height, self or proxy report, survey year, rural or urban residence, availability of irrigation in the municipality, and state of residence.

\section{Results}

\section{Descriptive Statistics}

Descriptive statistics are shown in Table 1 separately for nonmigrants, migrants whose first US trip was undocumented, and those whose first US trip was documented. These statistics were derived from the year of the first US trip for immigrants and the average across the observation window (age 15 to survey year) for nonmigrants. The sample of heads of household and spouses contained 1,448 undocumented migrants and 219 documented migrants. Whereas the descriptive statistics revealed some interesting differences, they should be interpreted with caution because they were not adjusted for important demographic and socioeconomic characteristics.

US migrants appeared to have better health at age 14 than nonmigrants. Between the two groups of immigrants, authorized immigrants had a slight health advantage, though the difference was small and non-significant. With respect to health endowments and risk behavior, 
migrants were taller and more likely to have ever smoked. The risk of smoking was particularly high among undocumented immigrants. Migrants were younger and more likely to be male. This was especially true for undocumented immigrants. Also, unauthorized migrants were least likely to be married and were the least educated comparing to authorized migrants and nonmigrants. In comparison, documented migrants represented the most educated group. Both groups of immigrants were less likely to own business or property than nonmigrants. As expected, both documented and undocumented migrants were more likely to be embedded in family and community migration networks. They were also more likely to originate from rural Mexico.

[Table 1 about here]

\section{Regression Results}

Results from the competing-risk event history analysis are presented in Table 2. For Mexican men, after accounting for compositional differences in demographic and socioeconomic characteristics, undocumented migrants were positively selected on health. In other words, having excellent health significantly increased the odds of undocumented US migration by $92 \%$. This, however, was not the case for documented US migration. Health was not significantly associated with documented US migration among men. For women, by contrast, excellent health promoted both types of US migration. Having excellent health increased the odds of undocumented and documented migration by $80 \%$ and $117 \%$ respectively. The difference between the two groups of female migrants was not statistically significant. These results suggest that men who were undocumented were positively selected on the basis of health, but this was not the case for their documented counterparts. For women, both documented and undocumented migrants were positively selected. 
[Table 2 about here]

The patterns are more clearly revealed in cumulative incidence curves in Figure 1 and 2. The figures show the cumulative probability of making an authorized or unauthorized trip over the course of one's life. For men (Figure 1), the likelihood of undocumented migration was much higher than that of documented migration. Having excellent health early in life increased the likelihood of undocumented US migration. Among men with excellent health, the cumulative incidence of unauthorized migration was $7.5 \%$ at age 30 , compared to $5 \%$ of their peers reporting less than excellent health. The gap between healthier and less healthy men grew over time such that by age 50 , the cumulative incidence was $20 \%$ and $15 \%$ respectively for those with excellent health and less than excellent health. Such patterns were not distinguishable for documented male migrants (right panel), suggesting no difference in the cumulative incidence of documented migration by health.

Among women (Figure 2), there were notable differences in the incidence of both documented and undocumented migration by health. The cumulative incidence of undocumented migration at age 50 was $25 \%$ for women with excellent health, compared to $15 \%$ for those with less than excellent health (left panel). The corresponding incidence for documented US migration was lower, at 5\% and $2.5 \%$ respectively (right panel). These results suggest that excellent health increased the likelihood of both types of migration among women. Compared to men, women's likelihood of undocumented and documented migration was lower that of men at each age (comparing Figure 1 and 2). This is consistent with previous research showing the domination of men in the Mexico-US migration flow (Cerrutti and Gaudio, 2010; Pedraza, 1991).

[Figure 1 and 2 about here] 
With respect to other factors in Table 2, height was significantly associated with undocumented US migration among women. Smoking significantly increased the likelihood of undocumented migration for men and of both types of migration for women. This result provides some evidence for the speculation that migrants are more risk prone than nonmigrants (Brindis et al., 1995; Riosmena et al., 2013). Higher education decreased the likelihood of unauthorized migration while increasing the chance of authorized migration. Business ownership reduced both types of US migration for men and undocumented migration for women. Property ownership, on the other hand, increased documented migration for men but reduced undocumented migration for women. Embeddedness in migration networks was a strong predictor of both types of migration and for both men and women. The pattern was true whether migration networks were measured at the family or community level. Undocumented male migrants were also more likely to originate from rural areas.

We examined a possible mechanism through which undocumented female migration exhibited a lower degree of health selectivity, namely an account of their reliance on family migration networks that reduced the risks of migration. Specifically, we assessed whether health selection was greater among undocumented female migrants with no family migrant networks than those whose family members had migration experience. We did so by including an interaction between health and family migration networks for women. The results are presented in Table 3 and Figure 3. The interaction was negative and significant, suggesting that women embedded in family migration networks were less selective on health than those who did not have these networks. Similarly in Figure 3, for women with relatives who were migrants, the likelihood of undocumented immigration was not significantly associated with health. By contrast, for women with no migrant relatives, having excellent health significantly increased the 
chance of undocumented migration. This result provided supporting evidence for the speculation that undocumented immigrant women were less selected on health because of the protective role of family migration networks. This finding also holds for men, further illustrating the important role of migration networks. For men, it seems that the lack of a health selection for documented migrants were largely driven by those with migrant networks.

[Table 3 and Figure 3 about here]

Turning to the number of undocumented US migration trips in Table 4, we find that for men, excellent health was positively and significantly associated with recurrent undocumented migration. This result provides further support for a greater degree of health selection for undocumented male immigrants: excellent health predicted not only the first undocumented migration but also subsequent unauthorized trips. For women, there was some weak indication of a positive relationship between health and repeated undocumented migration but the coefficient was non-significant. This result was consistent with our finding of a similar degree of positive health selection between documented and undocumented female migrants.

[Table 4 about here]

In terms of other covariates, among men, repeated unauthorized trips diminished with age, as well as with higher education and business ownership. Family migration networks facilitated repeated unauthorized migration for men but not women. Community migration networks, in contrast, decreased the likelihood of repeated unauthorized trips. This was aligned with previous research demonstrating a limited effect of community migration networks for subsequent migration trips relative to the initial trip (Massey and Espinosa, 1997). Once people had migrated to the US, they acquired knowledge and experience in border crossing and settlement, which substituted for community migration social capital. 
Several sensitivity analyses are presented in Appendix A. The top panel shows an analysis that uses different operationalizations of health. When SRH at age 14 was included as a continuous variable (higher values indicating better health), the results remained consistent with those reported in Table 2 and 4. There was a positive health selection for undocumented migration among men, and for both documented and undocumented migration among women. When we operationalized SRH as a categorical variable and distinguished among excellent, good, and regular and poor health, we again found a similar pattern. Also, the health selectivity was largely driven by individuals reporting excellent health. Excellent health facilitated repeated undocumented migration for men but not for women. The bottom panel of Appendix A shows models that did not control for height and smoking behavior, which yielded similar results.

Appendix B presents additional analyses restricted to different samples. The top panel presents an analysis that was restricted to individuals below age 35 at the time of the interview. This analysis addressed the issue of a time gap between early-life health (at age 14) and the time of the first migration trip. The time gap was relatively small for the younger age group and thus was of less concern. We see that the main results held in the subsample analysis, which increased our confidence that the gap between the health report and first migration was not a major concern. Note that this analysis could not be reliably estimated for women because the sample size of immigrant women under age 35 was extremely small. The middle panel presents the results for older immigrants (age 35-55), which was largely consistent with the main results.

Furthermore, the analysis in the bottom panel explored whether or not the absence of a positive health selection for documented migration among men may be partly explained by the long history of Mexico-US male migration that operates to reduce the costs of migration and hence the degree of selectivity. Specifically, we relaxed the sample age restriction to study all 
individuals aged 15 or older at the time of the interview. This step allowed us to include early cohorts of migrants who undertook US migration when the costs were high. We saw that a positive health selection for documented migration among men reemerged. This positive selection tended to be largely driven by individuals who engaged in the early stages of migration (e.g., who were not included in the sample for Table 2).

\section{Discussion and Conclusion}

The present study examines the heterogeneity of immigrant health selection by documentation status and by gender in the context of Mexico-US migration. The results reveal a substantial diversity in the migration selection process. For Mexican men, undocumented migrants were especially positively selected on health. Better pre-migration health also increased recurrent undocumented migration among men. Documented male migrants, in contrast, did not exhibit a positive health selection. For Mexican women, both authorized and unauthorized migration was positively selected on the basis of health and the degree of health selection did not differ by documentation status.

The findings contribute to the literature on immigrant health selection in several ways. First, our study extends previous research by demonstrating differential health selection by documentation status, particularly for men. The greater risks and difficulties of unauthorized migration and subsequent settlement raise the level of health selectivity. Good health positions unauthorized immigrants to endure the risky border crossing and precarious life conditions after arrival. As a result, health is a salient factor in undocumented migration decision-making.

Second, the present study shows how immigrant health selection operates differently by gender. The finding of the absence of a stronger positive health selection of undocumented 
migration among women may be explained by gender-specific circumstances surrounding the migration journey and settlement. For women, unauthorized migration entails lower risks (partly because of the protective effect of migration networks) and is less likely to be followed by employment. These conditions reduce selectivity, leading to a similar degree of health selection by documentation status among women. We explicitly tested the role of family migration networks and found support for the speculation that such networks reduced health selection of female migrants.

At the same time, authorized female migration is more selective than authorized male migration, partly owing to the long history of male Mexico-US migration. As male US migration has become more established over time, personal characteristics such as health have played a diminishing role in migration. This is especially true for authorized migration, whereas undocumented migration has been subject to consistently high barriers due to tightening border enforcement. For women, whose migration has increased but has continued to lag behind male migration, both documented and undocumented migration remain positively selected on personal characteristics.

Our results help reconcile mixed findings in previous research on the health selection of Mexican immigrants. We offer an additional explanation for the inconsistencies, that is, the degree of immigrant health selection tends to vary by both documentation status and gender. Studies that combine migrants of different status and both sexes are likely to obscure these differences, leading to an incomplete understanding. Cheong and Massey (2018) represents a notable exception that disaggregates the analysis by documentation status. However, that particular study combines men and women and finds no significant difference in health selection 
by status. This could be driven by the female sample, for which both documented and undocumented migrants were positive selected on health.

Documenting differential health selection is only a first step toward a better understanding of immigrant health. Along with militarization of the Mexico-US border, undocumented immigrants increasingly stay in the US for long periods of time (Massey et al., 2014). Tightening enforcement and anti-immigrant political rhetoric have created growingly restrictive and toxic environments that are harmful to the health of all immigrants (Rhodes et al., 2015), particularly undocumented immigrants (Amuedo-Dorantes et al., 2013; Martinez et al., 2015). Due to their legal vulnerability, unauthorized immigrants are also exposed to undesirable working conditions characterized by inadequate safety regulations and exploitations, which further increase the risk of injuries and illness (Flynn et al., 2015). These experiences and stressors likely accumulate to make undocumented immigrants especially susceptible to health deterioration (Torres and Young, 2016).

Taking into account differential health selection by documentation status is essential for an accurate assessment of the impact of unauthorized status on immigrant health and for meeting the healthcare needs of this population in many countries experiencing large immigration. Although unauthorized migrants tend to confront greater health challenges, they may appear healthier than their authorized peers and the native-born. This observation is misleading. Undocumented immigrants bring with them greater health endowments (i.e. greater positive health selection), which make them appear to have better health even when experiencing steep health deterioration. In this respect, studies investigating the health impacts of legal status should account for differential health selection by status in the first place. We hope that our study offers a framework for a more accurate understanding of immigrant health. 
Despite these contributions, our study is limited to the use of retrospective SRH. SRH is subject to bias related to what individuals choose as their reference group (i.e., if immigrants and nonmigrants assess their health relative to a different benchmark). Also, retrospective reports of health may be susceptible to recall bias. We are unable to evaluate the impact of these sources of bias. However, to the extent that immigrants, especially undocumented immigrants, confront substantial health challenges and are thus more likely to perceive less optimal health early in life, our estimates would be considered conservative. Given the paucity of data with information on pre-migration health and documentation status, we believe that the strengths of the MMP data outweigh the limitations inherent in retrospective self-reports.

There is a need for better data and more systematic investigation of variations in immigrant health selection and health outcomes by documentation status. Ideally, one would use longitudinal data with detailed histories of immigration and legal status, as well as a wide range of subjective and objective health measures at multiple points in time. Such data would allow for an accurate investigation of the impact of legal status on health while accounting for differences in immigrant health selectivity.

Although our study focuses on Mexico-US migration, the US has attracted documented and undocumented immigrants from diverse origin countries beyond Mexico. In other parts of the world, many countries have also experienced large flows of documented and documented migration. To some extent, Mexico-US migration represents a special case, which is characterized by geographical proximity and a significant economic gap between each side of the border. One would expect the costs and risks, and hence the degree of immigrant health selection and subsequent health outcomes, to vary across immigrant streams and contexts of migration. For example, undocumented immigration may be more physically demanding as the distance 
between origin and destination societies increases (especially when they are not contiguous). The recent tragedy involving Vietnamese immigrants in the UK attests to the precarious and perilous journey undocumented migrants endure (Mueller 2019). Despite the potential for heterogeneity, the conceptual and analytic framework developed in the present study can be adapted to other settings and, we hope, will inspire future research. 


\section{References}

Abraído-Lanza AF, Chao MT, Flórez KR. 2005. Do healthy behaviors decline with greater acculturation?: Implications for the Latino mortality paradox. Social Science and Medicine 61: 1243-1255 DOI: 10.1016/j.socscimed.2005.01.016

Abraído-Lanza AF, Dohrenwend BP, Ng-Mak DS, Turner JB. 1999. The Latino mortality paradox: A test of the 'salmon bias' and healthy migrant hypotheses. American Journal of Public Health 89: 1543-1548 DOI: 10.2105/AJPH.89.10.1543

Aguirre A, Simmers JK. 2008. Mexican border crossers: The Mexican body in immigration discourse. Social Justice 35: 99-106

Akresh IR, Frank R. 2008. Health selection among new immigrants. American Journal of Public Health 98: 2058-2064 DOI: 10.2105/AJPH.2006.100974

Amuedo-Dorantes C, Puttitanun T, Martinez-Donate AP. 2013. How do tougher immigration measures affect unauthorized immigrants? Demography 50: 1067-1091 DOI: 10.1007/s13524-013-0200-X

Andersson G, Drefahl S. 2017. Long-Distance Migration and Mortality in Sweden: Testing the Salmon Bias and Healthy Migrant Hypotheses. Population, Space and Place 23 DOI: 10.1002/psp.2032

Angel JL, Buckley CJ, Finch BK. 2010. Nativity and self-assessed health among pre-retirement age Hispanics and non-Hispanic Whites. International Migration Review 35: 784-803 DOI: 10.1111/j.1747-7379.2001.tb00041.x

Anglewicz P, VanLandingham M, Manda-Taylor L, Kohler HP. 2018. Health selection, migration, and HIV infection in Malawi. Demography 55: 979-1007 DOI: 10.1007/s13524018-0668-5

Antecol H, Bedard K. 2006. Unhealthy assimilation: why do immigrants converge to American health status levels? Demography 43: 337-60 DOI: DOI: 10.1353/dem.2006.0011

Asad AL, Clair M. 2018. Racialized legal status as a social determinant of health. Social Science and Medicine 199: 19-28 DOI: 10.1016/j.socscimed.2017.03.010

Beltrán-Sánchez H, Palloni A, Riosmena F, Wong R. 2016. SES Gradients Among Mexicans in the United States and in Mexico: A New Twist to the Hispanic Paradox? Demography 53: 1555-1581 DOI: 10.1007/s13524-016-0508-4

Benonnier T, Millock K, Taraz V. 2019. Climate change, migration, and irrigation. Working Paper

Biddle N, Kennedy S, Mcdonald JT. 2007. Health assimilation patterns amongst Australian Immigrants. Economic Record 83: 16-30 DOI: 10.1111/j.1475-4932.2007.00373.x

Briggs VM. 1993. Immigrant labor and the issue of 'dirty work' in advanced industrial societies. Population and Environment 14: 503-514 DOI: 10.1007/BF01276570

Brindis C, Wolfe AL, McCarter V, Ball S, Starbuck-Morales S. 1995. The associations between immigrant status and risk-behavior patterns in Latino adolescents. Journal of Adolescent Health 17: 99-105 DOI: 10.1016/1054-139X(94)00101-J

Case A, Paxson C. 2010. Causes and consequences of early-life health. Demography 47: 65-85 DOI: $10.1353 /$ dem.2010.0007

Castañeda H, Holmes SM, Madrigal D, Young M-ED, Beyeler N, Quesada J. 2015. Immigration as a social determinant of health. Annual Review of Public Health 36: 1-18 DOI:

10.1146/annurev-publhealth-032013-182419 
Castro FG. 2007. Is acculturation really detrimental to health? American Journal of Public Health 97: 1162-1162 DOI: 10.2105/ajph.2007.116145

Cerrutti M, Gaudio M. 2010. Gender differences between Mexican migration to the United States and Paraguayan migration to Argentina. Annals of the American Academy of Political and Social Science 630: 93-113 DOI: 10.1177/0002716210368105

Cheong AR, Massey DS. 2018. Undocumented and unwell: legal status and health among Mexican Migrants. DOI: 10.1177/0197918318775924

Chiswick BR, Lee YL, Miller PW. 2008. Immigrant selection systems and immigrant health. Contemporary Economic Policy 26: 555-578 DOI: 10.1111/j.1465-7287.2008.00099.x

Cornelius WA. 2001. Death at the border: efficacy and unintended consequences of US immigration control policy. Population and Development Review 27: 661-685 DOI: 10.1111/j.1728-4457.2001.00661.x

Curran SR, Shafer S, Donato KM. 2006. Mapping gender and migration in sociological scholarship: Is it segregation or integration? International Migration Review 40: 199-223 DOI: $10.1111 /$ j.1747-7379.2006.00008.x

Davis B, Winters P. 2001. Gender, networks and Mexico-US migration. Journal of Development Studies 38: 1-26 DOI: 10.1080/00220380412331322251

Diaz CJ, Zeng L, Martinez-Donate AP. 2018. Investigating health selection within Mexico and across the US border. Population Research and Policy Review 37: 181-204 DOI: 10.1007/s11113-017-9456-y

Docquier F, Rapoport H. 2009. Skilled immigration: The perspective of developing countries. In Skilled Immigration Today: Prospects, Problems, and Policies, Baghwati J, , Hanson G (eds).Russell Sage Foundation: New York.

Donato KM, Gabaccia D. 2015. Gender and International Migration. Russell Sage Foundation: New York.

Donato KM, Wagner B, Patterson E. 2008. The cat and mouse game at the Mexico-U.S. border: Gendered patterns and recent shifts. International Migration Review 42: 330-359 DOI: 10.1111/j.1747-7379.2008.00127.x

Durand J, Massey DS, Zenteno RM. 2001. Mexican immigration to the United States: Continuities and changes. Latin American research review 36: 107

Feliciano C. 2005. Educational selectivity in U.S. immigration: How do immigrants compare to those left behind? Demography 42: 131-152 DOI: 10.1353/dem.2005.0001

Flynn MA, Eggerth DE, Jacobson CJ. 2015. Undocumented status as a social determinant of occupational safety and health: The workers' perspective. American Journal of Industrial Medicine 58: 1127-1137 DOI: 10.1002/ajim.22531

Garip F. 2012. Repeat migration and remittances as mechanisms for wealth inequality in 119 communities from the Mexican Migration Project data. Demography 49: 1335-1360 DOI: 10.1007/s13524-012-0128-6

Guo S. 2010. Survival Analysis. Oxford University Press: Oxford.

Hagan JM. 1998. Social Networks, Gender, and Immigrant Incorporation: Resources and Constraints. American Sociological Review 63: 55-67 DOI: 10.2307/2657477

Hall M, Greenman E. 2015. The occupational cost of being illegal in the United States: Legal status, job hazards, and compensating differentials. International Migration Review 49: 406-442 DOI: 10.1111/imre.12090

Halliday T, Kimmitt MC. 2008. Selective migration and health in the USA, 1984-93. Population Studies 62: 321-334 DOI: 10.1080/00324720802339806 
Hamilton ER, Hale JM, Savinar R. 2019. Immigrant legal status and health: Legal status disparities in chronic conditions and musculoskeletal pain among Mexican-born farm workers in the United States. Demography 56 DOI: 10.1007/s13524-018-0746-8

Hamilton TG, Palermo T, Green TL. 2015. Health assimilation among Hispanic immigrants in the United States: The impact of ignoring arrival-cohort effects. Journal of Health and Social Behavior 56: 460-477 DOI: 10.1177/0022146515611179

Hayward MD, Heron M. 1999. Racial inequality in active life among adult Americans. Demography 36: 77-91 DOI: 10.2307/2648135

Idler EL, Benyamini Y. 1997. Self-rated health and mortality: A review of twenty-seven community studies. Journal of Health and Social Behavior 38: 21-37 DOI: $10.2307 / 2955359$

Jasso G, Massey DS. 2004. Immigrant health: selectivity and acculturation. 04/23. DOI: http://dx.doi.org/10.1920/wp.ifs.2004.0423

Kanaiapuni S. 2000. An analysis of men, women and gender in Mexico. Social Forces 78: 13111348 DOI: https://doi.org/10.1093/sf/78.4.1311

Kennedy S, Kidd MP, McDonald JT, Biddle N. 2015. The healthy immigrant effect: Patterns and evidence from four countries. Journal of International Migration and Integration 16: 317332 DOI: $10.1007 / \mathrm{s} 12134-014-0340-\mathrm{x}$

Krogstad JM, Passel JS, Cohn D. 2019. 5 facts about illegal immigration in the U.S. Available at: https://www.pewresearch.org/fact-tank/2019/06/12/5-facts-about-illegal-immigration-inthe-u-s/

Livingston G. 2006. Gender, job searching, and employment outcomes among Mexican immigrants. Population Research and Policy Review 25: 43-66 DOI: 10.1007/s11113-0060002-6

López G, Bialik K, Radford J. 2017. Key findings about U.S. immigrants Available at: http://www.pewresearch.org/fact-tank/2017/05/03/key-findings-about-u-s-immigrants/

Lu Y. 2008. Test of the 'healthy migrant hypothesis': A longitudinal analysis of health selectivity of internal migration in Indonesia. Social Science and Medicine 67: 1331-1339 DOI: 10.1016/j.socscimed.2008.06.017

Lu Y, Kaushal N, Denier N, Wang JSH. 2017. Health of newly arrived immigrants in Canada and the United States: Differential selection on health. Health and Place 48: 1-10 DOI: 10.1016/j.healthplace.2017.08.011

Lu Y, Qin L. 2014. Healthy migrant and salmon bias hypotheses: A study of health and internal migration in China. Social Science and Medicine 102: 41-48 DOI:

10.1016/j.socscimed.2013.11.040

Martinez O, Wu E, Sandfort T, Dodge B, Carballo-Dieguez A, Pinto R, Rhodes S, Moya E, Chavez-Baray S. 2015. Evaluating the impact of immigration policies on health status among undocumented immigrants: A systematic review. Journal of Immigrant and Minority Health 17: 947-970 DOI: 10.1007/s10903-013-9968-4

Massey D, Alarcón R, Durand J, González H. 1987. Return to Aztlan: The Social Process of International Migration from Western Mexico. University of California Press: Berkley, CA.

Massey DS. 2004. Measuring undocumented migration. International Migration Review 38: 1075-1102 DOI: 10.1111/j.1747-7379.2004.tb00229.x

Massey DS, Espinosa KE. 1997. What's driving Mexico-U.S. migration? A theoretical, empirical, and policy analysis. American Journal of Sociology 102: 939-999 DOI: $10.1086 / 231037$ 
Massey DS, Zenteno R. 2000. A validation of the ethnosurvey: The case of Mexico-U.S. migration. International Migration Review 34: 766-793 DOI: 10.2307/2675944

Massey DS, Durand J, Malone NJ. 2002. Beyond smoke and mirrors: Mexican immigration in an era of economic integration. Russell Sage Foundation: New York.

Massey DS, Durand J, Pren KA. 2014. Explaining undocumented migration to the U.S. International Migration Review 48: 1028-1061 DOI: 10.1111/imre.12151

Massey DS, Goldring L, Durand J. 1994. Continuities in transnational migration: A analysis of nineteen Mexican communities. American Journal of Sociology 99: 1492-1533 DOI: $10.1086 / 230452$

McDonald JT, Kennedy S. 2004. Insights into the 'healthy immigrant effect': Health status and health service use of immigrants to Canada. Social Science and Medicine 59: 1613-1627 DOI: 10.1016/j.socscimed.2004.02.004

Mueller, Benjamin. 2019. 39 Vietnamese died in a U.K. truck. 18,000 more endure this perilous trip. New York Times.

Orrenius PM, Zavodny M. 2005. Self-selection among undocumented immigrants from Mexico. Journal of Development Economics 78: 215-240 DOI: 10.1016/j.jdeveco.2004.07.001

Palloni A, Morenoff JD. 2001. Interpreting the paradoxical in the hispanic paradox: demographic and epidemiologic approaches. Annals of the New York Academy of Sciences 954: 140-74 Available at: http://www.ncbi.nlm.nih.gov/pubmed/11797855

Passel JS, Cohn D. 2009. A portrait of unauthorized immigrants in the United States Available at: www.pewhispanic.org

Pedraza S. 1991. Women and migration: the social consequences of gender. Annual Review of Sociology 17: 303-325 DOI: 10.1146/annurev.so.17.080191.001511

Reichert J, Massey DS. 1980. History and trends in U.S. bound Migration from a Mexican town. International Migration Review 14: 475-491 DOI: 10.2307/2545423

Rhodes SD, Mann L, Simán FM, Song E, Alonzo J, Downs M, Lawlor E, Martinez O, Sun CJ, O'Brien MC, et al. 2015. The impact of local immigration enforcement policies on the health of immigrant Hispanics/Latinos in the United States. American Journal of Public Health 105: 329-337 DOI: 10.2105/AJPH.2014.302218

Riosmena F, Kuhn R, Jochem WC. 2017. Explaining the immigrant health advantage: Selfselection and protection in health-related factors among five major national-origin immigrant groups in the United States. Demography 54: 175-200 DOI: 10.1007/s13524016-0542-2

Riosmena F, Wong R, Palloni A. 2013. Migration selection, protection, and acculturation in health: A binational perspective on older adults. Demography 50: 1039-1064 DOI: 10.1007/s13524-012-0178-9

Rubalcava LN, Teruel GM, Thomas D, Goldman N. 2008. The healthy migrant effect: New findings from the Mexican Family Life Survey. American Journal of Public Health 98: 7884 DOI: 10.2105/AJPH.2006.098418

Smith JP, Thomas D. 2003. Remembrances of things past: Test-retest reliability of retrospective migration histories. Journal of the Royal Statistical Society. Series A: Statistics in Society 166: 23-49 DOI: 10.1111/1467-985X.00257

Subramanian S V., Kawachi I. 2006. Whose health is affected by income inequality? A multilevel interaction analysis of contemporaneous and lagged effects of state income inequality on individual self-rated health in the United States. Health and Place 12: 141156 DOI: $10.1016 /$ j.healthplace.2004.11.001 
Swartz JJ, Hainmueller J, Lawrence D, Rodriguez MI. 2017. Expanding prenatal care to unauthorized immigrant women and the effects on infant health. Obstetrics and Gynecology 130: 938-945 DOI: 10.1016/j.ehb.2018.06.002

Torres JM, Young MED. 2016. A life-course perspective on legal status stratification and health. SSM - Population Health 2: 141-148 DOI: 10.1016/j.ssmph.2016.02.011

U.S. Department of State. 2013. Immigrant and Nonimmigrant Visa Ineligibilities Available at: https://ravel.state.gov/content/dam/visas/Statistics/AnnualReports/FY2013AnnualReport/F Y13AnnualReport-TableXX.pdf [Accessed 5 October 2019]

Ullmann SH, Goldman N, Massey DS. 2011. Healthier before they migrate, less healthy when they return? The health of returned migrants in Mexico. Social Science and Medicine 73: 421-428 DOI: 10.1016/j.socscimed.2011.05.037

Villarreal A, Hamilton ER. 2012. Rush to the border? Market liberalization and urban- and ruralorigin internal migration in Mexico. Social Science Research 41: 1275-1291 DOI: 10.1016/j.ssresearch.2012.02.007

Wallace M, Kulu H. 2014. Migration and Health in England and Scotland: A Study of Migrant Selectivity and Salmon Bias. Population, Space and Place 20: 694-708 DOI: $10.1002 /$ psp. 1804

Wallace M, Kulu H. 2018. Can the salmon bias effect explain the migrant mortality advantage in England and Wales? Population, Space and Place 24 DOI: 10.1002/psp.2146

Wasem RE. 2014. Immigration Policies and Issues on Health-Related Groups for Exclusion. Congressional Research Service, Washington, DC. Available at: https://fas.org/sgp/crs/homesec/R40570.pdf

Waters MC, Pineau MG. 2016. The integration of immigrants into American society (MC Waters and MG Pineau, eds). National Academies Press: Washington, DC.

Wen M, Maloney TN. 2014. Neighborhood socioeconomic status and BMI differences by immigrant and legal status: Evidence from Utah. Economics and Human Biology 12: 120 131 DOI: 10.1016/j.ehb.2013.03.008

Young MEDT, Madrigal DS. 2017. Documenting legal status: A systematic review of measurement of undocumented status in health research. Public Health Reviews 38: 1-25 DOI: $10.1186 / \mathrm{s} 40985-017-0073-4$ 


\section{Figures}

Figure 1. Cumulative incidence of undocumented and documented male immigrants by health status
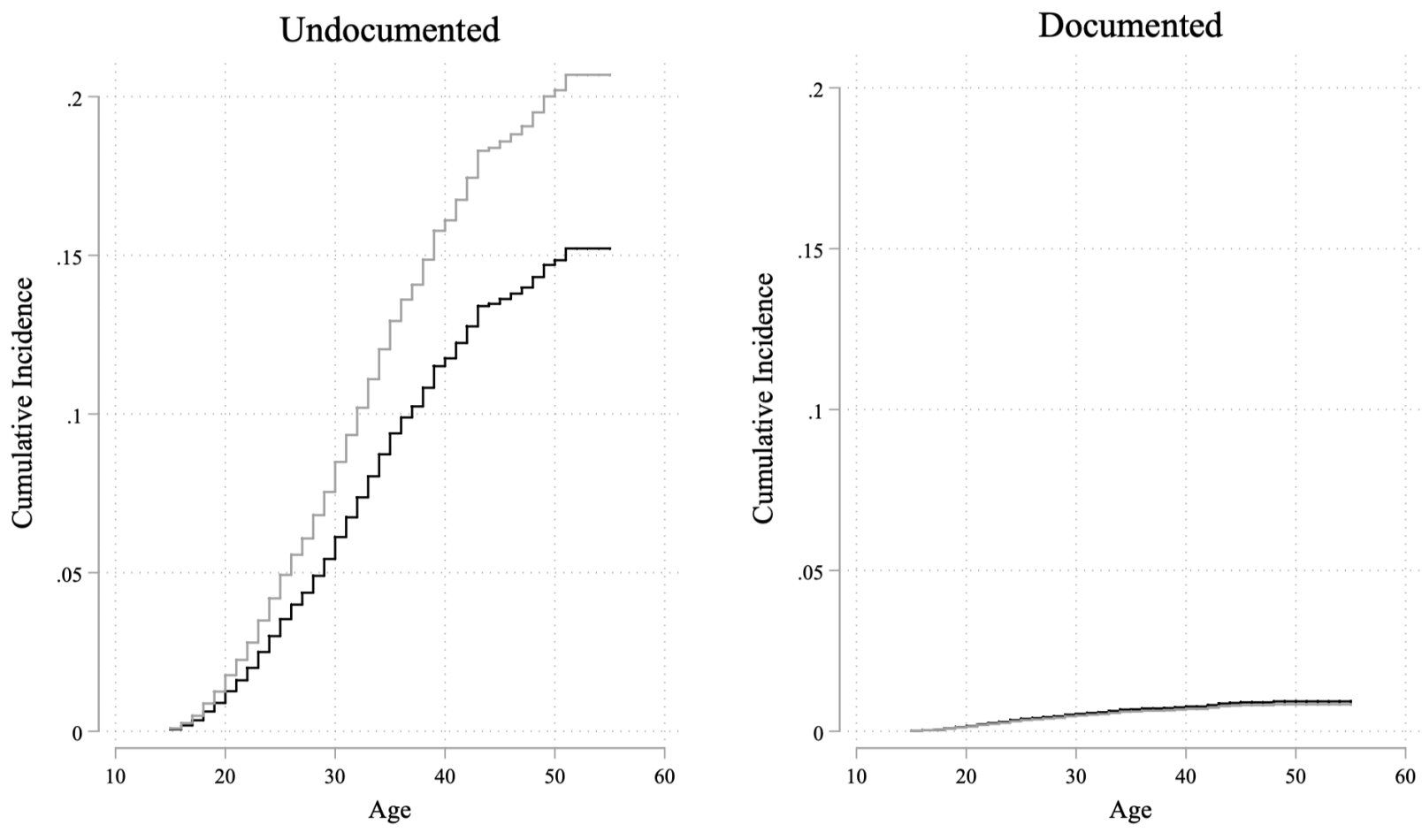

Good, fair, or poor health at age 14

Excellent health at age 14 
Figure 2. Cumulative incidence of undocumented and documented female immigrants by health status
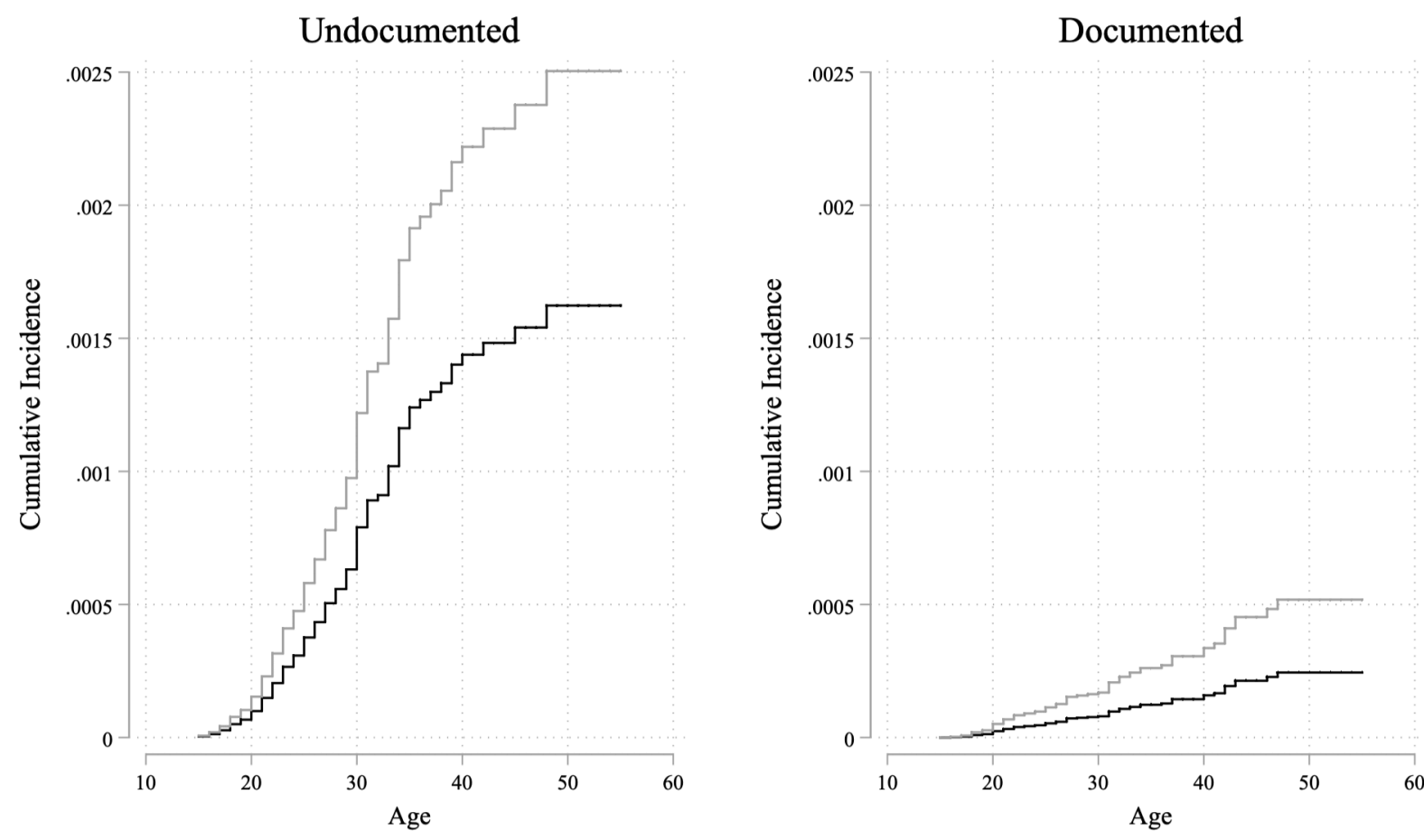

- Good, fair, or poor health at age 14

Excellent health at age 14 
Figure 3. Predicted Probabilities of Undocumented Migration by Gender and Migration Networks

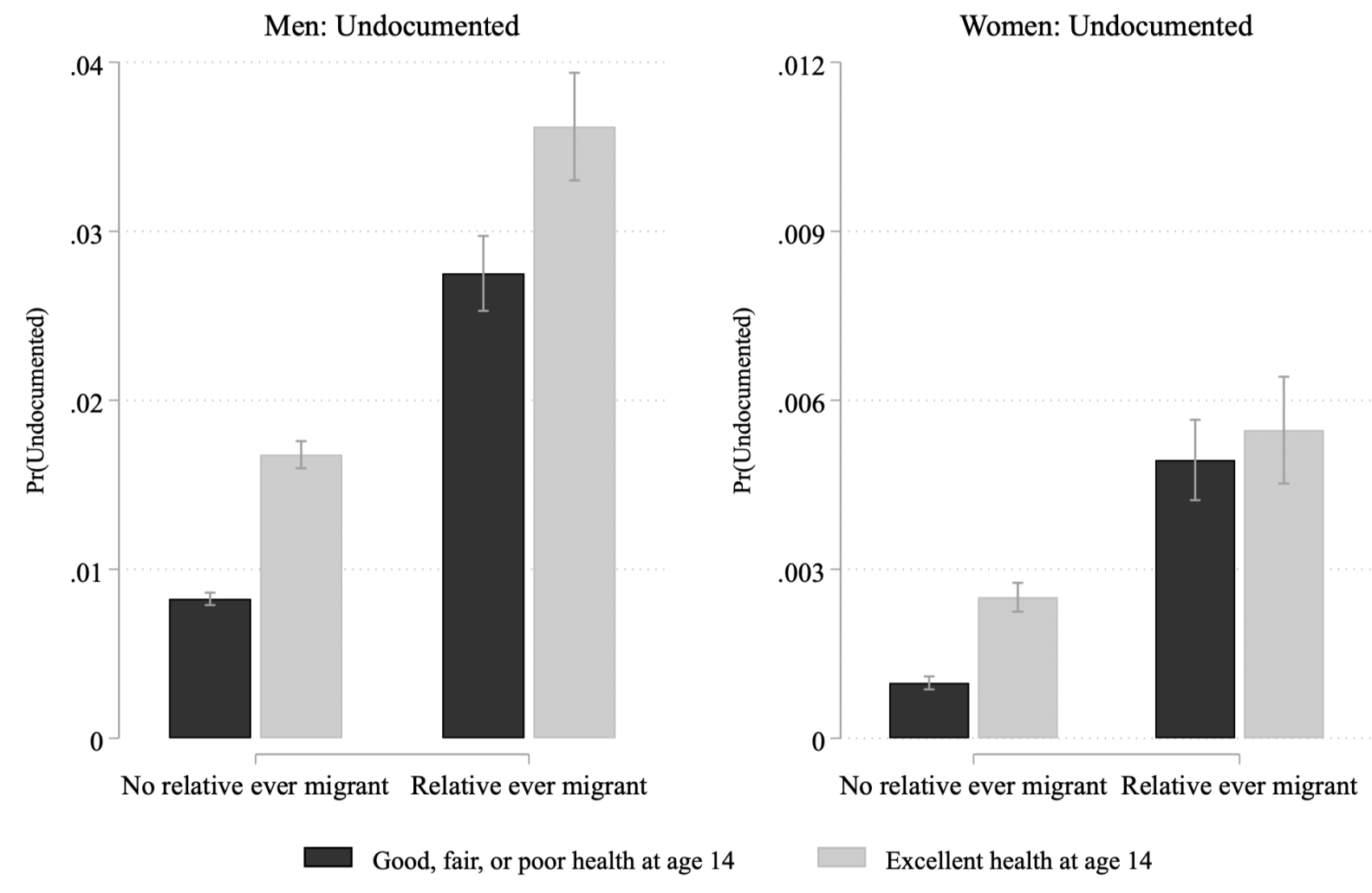

Note: Predicated probabilities based on average marginal effects. 
Tables

Table 1. Descriptive Statistics of Variables Used in the Analysis

\begin{tabular}{lcccc}
\hline & All & Nonmigrants & Undocumented & Documented \\
\hline Excellent health at age 14 & 0.329 & 0.328 & 0.470 & 0.493 \\
Height $(\mathrm{cm})$ & 160.9 & 160.9 & 166.2 & 166.5 \\
& $(9.379)$ & $(9.372)$ & $(8.639)$ & $(9.664)$ \\
Ever smoked & 0.120 & 0.119 & 0.249 & 0.182 \\
Male & 0.423 & 0.420 & 0.826 & 0.643 \\
Age & 29.167 & 29.204 & 23.896 & 26.520 \\
& $(9.413)$ & $(9.419)$ & $(6.945)$ & $(7.624)$ \\
Married & 0.708 & 0.709 & 0.511 & 0.648 \\
Years of education & 7.625 & 7.624 & 7.477 & 9.415 \\
& $(3.717)$ & $(3.721)$ & $(3.086)$ & $(3.782)$ \\
Business ownership & 0.172 & 0.173 & 0.064 & 0.055 \\
Property ownership & 0.438 & 0.439 & 0.228 & 0.360 \\
Relative ever migrant & 0.118 & 0.116 & 0.257 & 0.255 \\
Migration prevalence ratio & 0.091 & 0.090 & 0.136 & 0.165 \\
& $(0.084)$ & $(0.083)$ & $(0.098)$ & $(0.101)$ \\
Self report & 0.477 & 0.478 & 0.441 & 0.461 \\
Rural & 0.647 & 0.646 & 0.753 & 0.794 \\
Irrigation in municipality & 0.854 & 0.854 & 0.829 & 0.835 \\
Number of individuals & 10,032 & 8,366 & 1,447 & 219 \\
\hline
\end{tabular}

Note: Standard deviations are in parentheses. 
Table 2. Discrete-time Multinomial Logit Model Predicting Documented vs. Undocumented First Trip to the United States (reference $=$ nonmigrants)

\begin{tabular}{|c|c|c|c|c|}
\hline \multirow[b]{2}{*}{ Independent Variables } & \multicolumn{2}{|c|}{ Men } & \multicolumn{2}{|c|}{ Women } \\
\hline & Undocumented & Documented & Undocumented & Documented \\
\hline Excellent health at age 14 & $\begin{array}{c}0.653 * * * \\
(0.064)\end{array}$ & $\begin{array}{c}0.329 \\
(0.197)\end{array}$ & $\begin{array}{c}0.587 * * * \\
(0.136)\end{array}$ & $\begin{array}{c}0.776 * * \\
(0.263)\end{array}$ \\
\hline Height (cm) & $\begin{array}{c}0.007 \\
(0.004)\end{array}$ & $\begin{array}{c}0.016 \\
(0.011)\end{array}$ & $\begin{array}{c}0.031 * * * \\
(0.009)\end{array}$ & $\begin{array}{c}0.029 \\
(0.016)\end{array}$ \\
\hline Ever smoked & $\begin{array}{c}0.153 * \\
(0.067)\end{array}$ & $\begin{array}{l}-0.206 \\
(0.211)\end{array}$ & $\begin{array}{c}0.712 * * \\
(0.260)\end{array}$ & $\begin{array}{c}0.860 * \\
(0.371)\end{array}$ \\
\hline Married & $\begin{array}{c}0.081 \\
(0.082)\end{array}$ & $\begin{array}{c}0.463 \\
(0.240)\end{array}$ & $\begin{array}{c}0.217 \\
(0.156)\end{array}$ & $\begin{array}{l}-0.132 \\
(0.287)\end{array}$ \\
\hline Years of education & $\begin{array}{c}-0.045^{* * *} \\
(0.009)\end{array}$ & $\begin{array}{c}0.113 * * * \\
(0.025)\end{array}$ & $\begin{array}{l}-0.017 \\
(0.020)\end{array}$ & $\begin{array}{c}0.116^{* * *} \\
(0.033)\end{array}$ \\
\hline Business ownership & $\begin{array}{c}-0.495^{* * *} \\
(0.122)\end{array}$ & $\begin{array}{c}-1.381 * * \\
(0.468)\end{array}$ & $\begin{array}{c}-1.153 * * * \\
(0.317)\end{array}$ & $\begin{array}{l}-0.717 \\
(0.412)\end{array}$ \\
\hline Property ownership & $\begin{array}{l}-0.094 \\
(0.082)\end{array}$ & $\begin{array}{l}0.460^{*} \\
(0.215)\end{array}$ & $\begin{array}{c}-0.776 * * * \\
(0.178)\end{array}$ & $\begin{array}{c}0.008 \\
(0.274)\end{array}$ \\
\hline Relative ever migrant & $\begin{array}{c}0.925 * * * \\
(0.075)\end{array}$ & $\begin{array}{c}1.023 * * * \\
(0.218)\end{array}$ & $\begin{array}{c}1.073 * * * \\
(0.146)\end{array}$ & $\begin{array}{c}0.731 * * \\
(0.279)\end{array}$ \\
\hline Migration prevalence ratio & $\begin{array}{c}4.406^{* * *} \\
(0.477)\end{array}$ & $\begin{array}{c}10.433^{* * *} \\
(1.169)\end{array}$ & $\begin{array}{c}5.519 * * * \\
(0.962)\end{array}$ & $\begin{array}{l}4.364^{*} \\
(1.844)\end{array}$ \\
\hline Self report & $\begin{array}{c}0.267 * * * \\
(0.068)\end{array}$ & $\begin{array}{c}0.347 \\
(0.203)\end{array}$ & $\begin{array}{c}0.092 \\
(0.140)\end{array}$ & $\begin{array}{c}0.404 \\
(0.260)\end{array}$ \\
\hline Rural & $\begin{array}{l}0.186^{*} \\
(0.084)\end{array}$ & $\begin{array}{c}0.500 \\
(0.344)\end{array}$ & $\begin{array}{c}0.237 \\
(0.197)\end{array}$ & $\begin{array}{c}0.231 \\
(0.400)\end{array}$ \\
\hline Irrigation in municipality & $\begin{array}{l}-0.213 \\
(0.112)\end{array}$ & $\begin{array}{c}0.144 \\
(0.349)\end{array}$ & $\begin{array}{l}-0.375 \\
(0.226)\end{array}$ & $\begin{array}{l}-0.719 * \\
(0.332)\end{array}$ \\
\hline Age dummies & Yes & Yes & Yes & Yes \\
\hline Survey year dummies & Yes & Yes & Yes & Yes \\
\hline State dummies & Yes & Yes & Yes & Yes \\
\hline Constant & $\begin{array}{c}-6.498 * * * \\
(0.754)\end{array}$ & $\begin{array}{c}-13.481 * * * \\
(2.151)\end{array}$ & $\begin{array}{c}-13.099 * * * \\
(1.732)\end{array}$ & $\begin{array}{c}-13.597 * * * \\
(2.939)\end{array}$ \\
\hline Person years & 93 & & 127 & \\
\hline
\end{tabular}

Note: Standard errors are in parentheses. ${ }^{* * *} \mathrm{p}<0.001,{ }^{* *} \mathrm{p}<0.01,{ }^{*} \mathrm{p}<0.05, \dagger \mathrm{p}<0.1$ (two-tailed tests) 
Table 3. Discrete-time Multinomial Logit Model of Interaction by Female and Migration Networks (reference $=$ nonmigrants)

\begin{tabular}{|c|c|c|c|c|}
\hline \multirow[b]{2}{*}{ Independent Variables } & \multicolumn{2}{|c|}{ Men } & \multicolumn{2}{|c|}{ Women } \\
\hline & Undocumented & Documented & Undocumented & Documented \\
\hline \multirow[t]{2}{*}{ Excellent health at age 14} & $0.766^{* * *}$ & $0.637 * *$ & $0.862 * * *$ & $0.671 *$ \\
\hline & $(0.072)$ & $(0.220)$ & $(0.166)$ & $(0.297)$ \\
\hline \multirow[t]{2}{*}{ Relative ever migrant } & $1.248 * * *$ & $1.705 * * *$ & $1.634 * * *$ & 0.509 \\
\hline & $(0.097)$ & $(0.269)$ & $(0.191)$ & $(0.481)$ \\
\hline Excellent health at age $14^{*}$ & $-0.436^{* *}$ & $-1.062 *$ & $-0.830 * *$ & 0.457 \\
\hline Relative ever migrant & $(0.142)$ & $(0.437)$ & $(0.278)$ & $(0.571)$ \\
\hline Control variables & Yes & Yes & Yes & Yes \\
\hline Person years & \multicolumn{2}{|c|}{93,551} & \multicolumn{2}{|c|}{127,620} \\
\hline
\end{tabular}

Notes: Control variables in the model include height $(\mathrm{cm})$, ever smoked, married, years of education, business ownership, property ownership, relative ever migrant, migration prevalence ratio, self report, rural, irrigation in municipality, age dummies, survey year dummies, and state dummies.

Standard errors are in parentheses. ${ }^{* * *} \mathrm{p}<0.001,{ }^{* *} \mathrm{p}<0.01,{ }^{*} \mathrm{p}<0.05, \dagger \mathrm{p}<0.1$ (two-tailed tests) 
Table 4. Negative binomial regressions predicting undocumented trips to the United States

\begin{tabular}{|c|c|c|}
\hline \multirow[b]{2}{*}{ Independent Variables } & Men & \multirow{2}{*}{$\begin{array}{c}\text { Women } \\
\text { No. of undocumented }\end{array}$} \\
\hline & No. of undocumented & \\
\hline \multirow[t]{2}{*}{ Excellent health at age 14} & $0.255^{* * *}$ & 0.276 \\
\hline & $(0.067)$ & $(0.349)$ \\
\hline \multirow[t]{2}{*}{ Height (cm) } & -0.003 & 0.018 \\
\hline & $(0.004)$ & $(0.026)$ \\
\hline \multirow[t]{2}{*}{ Ever smoked } & $-0.183^{* *}$ & -0.466 \\
\hline & $(0.067)$ & $(0.611)$ \\
\hline \multirow[t]{2}{*}{ Age } & $-0.124^{* * *}$ & $-0.133^{* * *}$ \\
\hline & $(0.005)$ & $(0.026)$ \\
\hline \multirow[t]{2}{*}{ Married } & $0.337^{* * *}$ & -0.290 \\
\hline & $(0.073)$ & $(0.356)$ \\
\hline \multirow[t]{2}{*}{ Years of education } & $-0.049 * * *$ & -0.053 \\
\hline & $(0.014)$ & $(0.057)$ \\
\hline \multirow[t]{2}{*}{ Business ownership } & $-0.644 * * *$ & $-2.165^{*}$ \\
\hline & $(0.129)$ & $(1.031)$ \\
\hline \multirow[t]{2}{*}{ Property ownership } & -0.067 & -0.854 \\
\hline & $(0.086)$ & $(0.480)$ \\
\hline \multirow[t]{2}{*}{ Relative ever migrant } & $0.211^{* *}$ & 0.572 \\
\hline & $(0.078)$ & $(0.392)$ \\
\hline \multirow[t]{2}{*}{ Migration prevalence ratio } & $-1.183^{*}$ & 0.811 \\
\hline & $(0.473)$ & $(2.290)$ \\
\hline \multirow[t]{2}{*}{ Self report } & 0.086 & $2.253^{* * *}$ \\
\hline & $(0.064)$ & $(0.528)$ \\
\hline \multirow[t]{2}{*}{ Rural } & $0.184^{*}$ & 0.157 \\
\hline & $(0.074)$ & $(0.481)$ \\
\hline \multirow[t]{2}{*}{ Irrigation in municipality } & 0.057 & 0.828 \\
\hline & $(0.115)$ & $(0.669)$ \\
\hline Survey year dummies & Yes & Yes \\
\hline State dummies & Yes & Yes \\
\hline \multirow[t]{2}{*}{ Constant } & $2.639 * * *$ & -20.277 \\
\hline & $(0.800)$ & $(907.298)$ \\
\hline Number of individuals & 4,587 & 5,445 \\
\hline
\end{tabular}




\section{Appendix}

Appendix A. Regression models predicting documentation by different coding of health status and without height/smoke

\begin{tabular}{lcccc}
\hline & \multicolumn{2}{c}{$\begin{array}{c}\text { Discrete-time multinomial } \\
\text { logit }\end{array}$} & & $\begin{array}{c}\text { Negative } \\
\text { binomial }\end{array}$ \\
\cline { 2 - 3 } Independent Variables & Undocumented & Documented & & $\begin{array}{c}\text { No. of } \\
\text { undocumented }\end{array}$ \\
\cline { 5 - 5 } Different Coding of Health Status & & & \\
Male: Continuous Health & $0.565^{* * *}$ & 0.278 & \\
Health at age 14 (continuous) & $(0.059)$ & $(0.174)$ & & $(0.059)$ \\
Control variables & Yes & Yes & & Yes
\end{tabular}

Male: Categorical Health

Health at age 14 (ref. $=$ good $)$

$\begin{array}{cccc}\text { Excellent } & 0.648^{* * *} & 0.327 & 0.254^{* * *} \\ & (0.065) & (0.199) & (0.068) \\ \text { Regular or Poor } & -0.095 & -0.037 & 0.039 \\ & (0.178) & (0.437) & (0.163) \\ & \text { Yes } & \text { Yes } & \text { Yes }\end{array}$

Control variables

$\begin{array}{cc}0.396^{* *} & 0.507^{*} \\ (0.121) & (0.234) \\ \text { Yes } & \text { Yes }\end{array}$

0.200

Health at age 14 (continuous)

Control variables

Female: Categorical Health

(0.291)

Yes

Health at age 14 (ref. = good)

Control variables

$\begin{array}{cccc}\text { Excellent } & 0.623 * * * & 0.849 * * & 0.241 \\ & (0.140) & (0.273) & (0.355) \\ \text { Regular or Poor } & 0.399 & 0.736 & -0.407 \\ & (0.300) & (0.553) & (0.838) \\ & \text { Yes } & \text { Yes } & \text { Yes }\end{array}$

\section{Not Controlling Height and Smoking}

Male: Excellent health at age 14

$0.665 * * *$

0.308

$0.171 * *$

Control variables

(0.063)

(0.193)

(0.053)

Yes

Yes

Yes

Female: Excellent health at age 14

$0.616^{* * *}$

$0.762 * *$

0.479

(0.134)

(0.261)

(0.336)

Control variables

Yes

Yes

Yes

Note: Standard errors are in parentheses. ${ }^{* * *} \mathrm{p}<0.001,{ }^{* *} \mathrm{p}<0.01,{ }^{*} \mathrm{p}<0.05, \dagger \mathrm{p}<0.1$ (two-tailed tests) 
Appendix B. Discrete-time Multinomial Logit Model Predicting Documented vs. Undocumented First Trip to the United States (reference = nonmigrant) for Different Age Groups

\begin{tabular}{|c|c|c|c|c|}
\hline \multirow[b]{2}{*}{ Independent Variables } & \multicolumn{2}{|c|}{ Men } & \multicolumn{2}{|c|}{ Women } \\
\hline & Undocumented & Documented & Undocumented & Documented \\
\hline \multicolumn{5}{|l|}{ Age 15-34 } \\
\hline Excellent health at age 14 & $\begin{array}{c}0.569 * * * \\
(0.142)\end{array}$ & $\begin{array}{l}-0.171 \\
(0.357)\end{array}$ & -- & -- \\
\hline Control variables & Yes & Yes & & \\
\hline $\begin{array}{l}\text { Person years } \\
\text { Age 35-55 }\end{array}$ & \multicolumn{2}{|c|}{14,039} & & \\
\hline Excellent health at age 14 & $\begin{array}{c}0.665^{* * *} \\
(0.072)\end{array}$ & $\begin{array}{c}0.454 \\
(0.249)\end{array}$ & $\begin{array}{c}0.606^{* * *} \\
(0.153)\end{array}$ & $\begin{array}{l}0.699 * \\
(0.292)\end{array}$ \\
\hline Control variables & Yes & Yes & Yes & Yes \\
\hline $\begin{array}{l}\text { Person years } \\
\text { Age } 15-102\end{array}$ & \multicolumn{2}{|c|}{79,519} & \multicolumn{2}{|c|}{105,336} \\
\hline Excellent health at age 14 & $\begin{array}{c}0.554 * * * \\
(0.056)\end{array}$ & $\begin{array}{c}0.503 * * * \\
(0.133)\end{array}$ & $\begin{array}{c}0.597 * * * \\
(0.118)\end{array}$ & $\begin{array}{c}0.690 * * * \\
(0.203)\end{array}$ \\
\hline Control variables & Yes & Yes & Yes & Yes \\
\hline Person years & \multicolumn{2}{|c|}{185,672} & \multicolumn{2}{|c|}{229,910} \\
\hline
\end{tabular}

